\title{
14. Exposing the transnational precarity of Filipino workers, healthcare regimes, and nation states
}

Francesca Humi

Following the outbreak of COVID-I9, academics and researchers across social science fields highlighted the ramifications of the pandemic for the movement of people across borders, ranging from the implications of the pandemic on global remittance flows to the geographies on grief, intimacy, and loss (Abel and Gietel-Basten 2020; Maddrell 2020). These pieces of preliminary research highlighted the inherent international and globalised state of the world in the 2ist century. The experience of one group, however, emerged as an ideal subject of study and poignant symbol of the impact of the pandemic on the most vulnerable, those at the frontlines, and those whose existence has been inherently diasporic and fragmented - in short, those whose lives intersected with all things most impacted by the COVID-I 9 health, social, and economic crises. That is, the globalised Filipino healthcare community.

This chapter examines the precarity of Filipino healthcare workers caught in between nation states' duties of care by focusing on those in the Philippines and the UK and by drawing on studies of Filipino labour migration and COVID-era commentary on Filipino healthcare workers in the two countries. This study posits that the Filipino experience is indicative of how migrant labour is controlled and exploited under globalised capitalism and by modern nation states in both the pre- and post-COVID worlds, ${ }^{\mathrm{I}}$ and calls for voices from the community to be given due consideration and audience.

\section{The global Filipino nation}

In 2013, over Io million Filipinos lived abroad, about 10\% of the country's total population (Commission on Filipinos Overseas 2013)

How to cite this book chapter:

Humi, Francesca. 2022. 'Exposing the transnational precarity of Filipino workers, healthcare regimes, and nation states'. In: Shin, Hyun Bang; Mckenzie, Murray; and Oh, Do Young (eds) COVID-I9 in Southeast Asia: Insights for a post-pandemic world. London: LSE Press, pp. I62-I7I. DOI: https://doi.org/IO.3 I $389 /$ lsepress.cov.n License: CC BY 4.०. 
without accounting for second-, third-, or fourth-generation Filipinos around the globe. Migration flows from the Philippines have been shaped by experiences of colonialism and economic intervention from international organisations (Parreñas 200I, p.I0). But the migration pattern of medical professionals has been particularly steeped in colonial legacies. American colonial rule in the Philippines from I898 to I 946 established nursing as a medical profession through training programmes and teaching hospitals (Choy 2003, p.I9). This was part of the US's mission of 'benevolent assimilation', which positioned health and education as a means to achieve self-rule (Choy 2003, pp.20-2I). It was also specifically designed to bring Filipino nurses to the US away from the Philippines (Choy 2003, p.5). In 2020, about 20,000 Filipinos worked for the UK's National Health Service (NHS), the largest group after British and Indian workers (Baker 2020). Although this presence originated in the US colonial period, the I990s saw the first major wave of Filipino nurses and other high-skilled workers migrating abroad, including to the UK, facilitated by Philippine government bodies and programmes (Choy 2003, p.I).

The Filipino experience can be taken as representative of a fragile, globalised system relying on the mobile and docile labour of migrants for their work both in their destination country and 'back home', where they provide remittances as well as stability for the Philippines' 'export-based economy' (Parreñas 200I, p.I I). Though the Filipino nation has become disconnected due to physical boundaries and political borders - and, more recently, a global pandemic - it is connected through an imagined global community, to borrow Benedict Anderson's (I983) concept of the nation, and through shared occupations and similar socio-economic status (Parreñas, 200I, p.I2). This is an archipelagic experience - by virtue of its geography and diaspora - shifting the focus from the national to a more dispersed and fragmented one, still connected through an imagined bond (David 2018, p.335).

The impact of COVID-I9 on this global Filipino nation has been documented by journalists, commentators, and academics alike. Galam (2020) has emphasised the role of community care among Filipino migrants in the UK, which stepped in where governments took a step back. Many have lauded the heroism demonstrated by Filipino healthcare workers and mourned the devastating toll the pandemic had on the community because of this and of broader structural issues from defunding of public health services to immigration regimes and legacies of racism and colonialism (Chikoko 2020; Day 202I). ${ }^{2}$ For many in 
the community, it felt like Filipino healthcare workers were receiving long-awaited recognition (Isidro 2020), but the complex and at times tragic realities for Filipino healthcare workers have warranted further exploration.

\section{The failure of two 'hero' narratives}

While the global economy's exploitation of and dependency on Filipino labour have earned Filipino migrants the titles of 'servants of globalisation' (Parreñas 200I) and 'manufactur[ed] heroes' (Guevarra 2009) forming an 'empire of care' (Choy 2003), the crises caused by COVID-I 9 have cast new light on this phenomenon. Shortly after the pandemic outbreak, the Philippine government halted the deployment of healthcare workers abroad even if they had signed contracts to return to work abroad, while asking them to 'volunteer' at home for 500 Philippine pesos (about US\$ IO) a day (Magsambol 2020). The ban was partially lifted in April 2020 (Calonzo 2020), but in 202I the Philippine government offered healthcare workers to Germany and the UK in exchange for vaccines (Morales 202I). The government's decisions to call on 'healthcare warriors' (Magsambol 2020) to save the country from public health disaster and then offer them as a bartering tool for vaccines demonstrated the pressure exerted by the global economy and its reliance on workers' willingness to sacrifice themselves for the benefit of society.

In the UK, as early as May 2020, Filipinos were the single largest nationality to die from coronavirus among NHS staff. They accounted for $22 \%$ of COVID-I9 deaths among nurses, despite Filipino nurses comprising only $3.8 \%$ of the nursing workforce (Kearney et al. 2020). By April 202I, at least 7I Filipino health and social care workers had died after contracting COVID-I9, according to the data collected by the Kanlungan Filipino Consortium (hereafter Kanlungan) - a charity working to support the Filipino migrant community in the UK (Day 202I).

Filipino healthcare workers were placed at the intersection of two separate, but overlapping, hero narratives. Healthcare workers in the UK and around the globe were hailed as heroes and applauded as model citizens during the pandemic (Mohammed et al. 202I, p.4). In the Philippines, the push to work abroad was bolstered by popular narratives of the overseas Filipino worker (OFW) as a 'modern-day hero' who endures tremendous hardship to form the backbone of the Philippines' economy (Almendral 20I 8; Rocamora 20I 8). Their remittances, which contributed about I०\% of the country's gross domestic product in 20I9 (World Bank 20I9), represented education and material stability 
for people at home. As a Facebook tribute to Dondee, a Filipino NHS nurse who died from COVID-r9 in April 2020, pointed out, '[h]e was the breadwinner of his family back home and helping 3 of his nieces/ nephews to college' (Fernandez 2020).

Workers like Dondee may have been attributed the status of hero but

Figure 14.1. A Filipino woman with groceries delivered by Kanlungan volunteers in London, April 2020

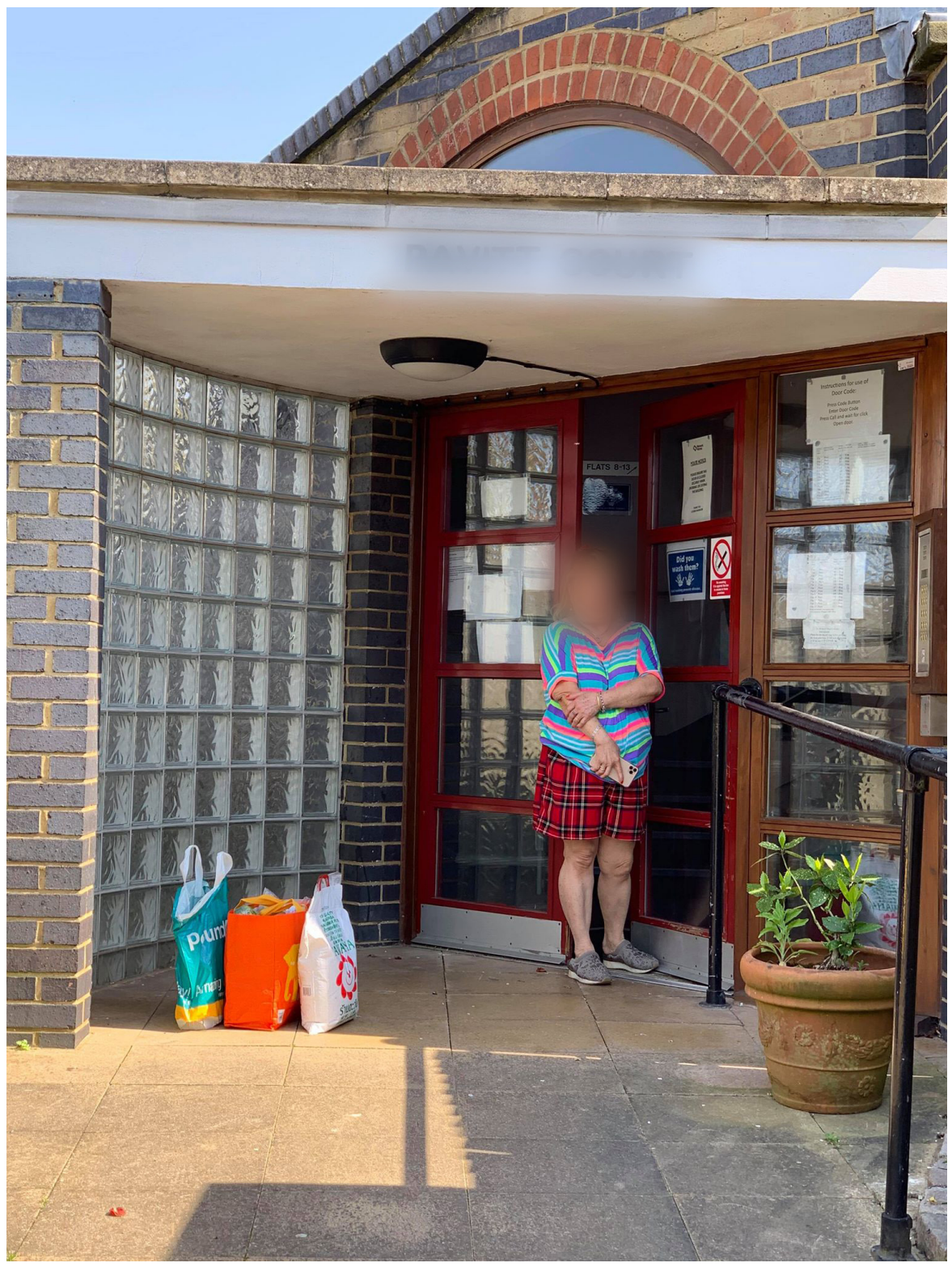

Source: Courtesy of Kanlungan. 
it did not provide him or his family with a changed material reality. Such attribution was, in fact, a tactic to deflect responsibility from politicians (Mohammed et al. 202I, p.8). Being an NHS hero receiving doorstep

Figure 14.2. Posters appealing for donations and volunteers for Kanlungan's COVID-I9 community outreach project in a Filipino grocery store window in London, April 2020

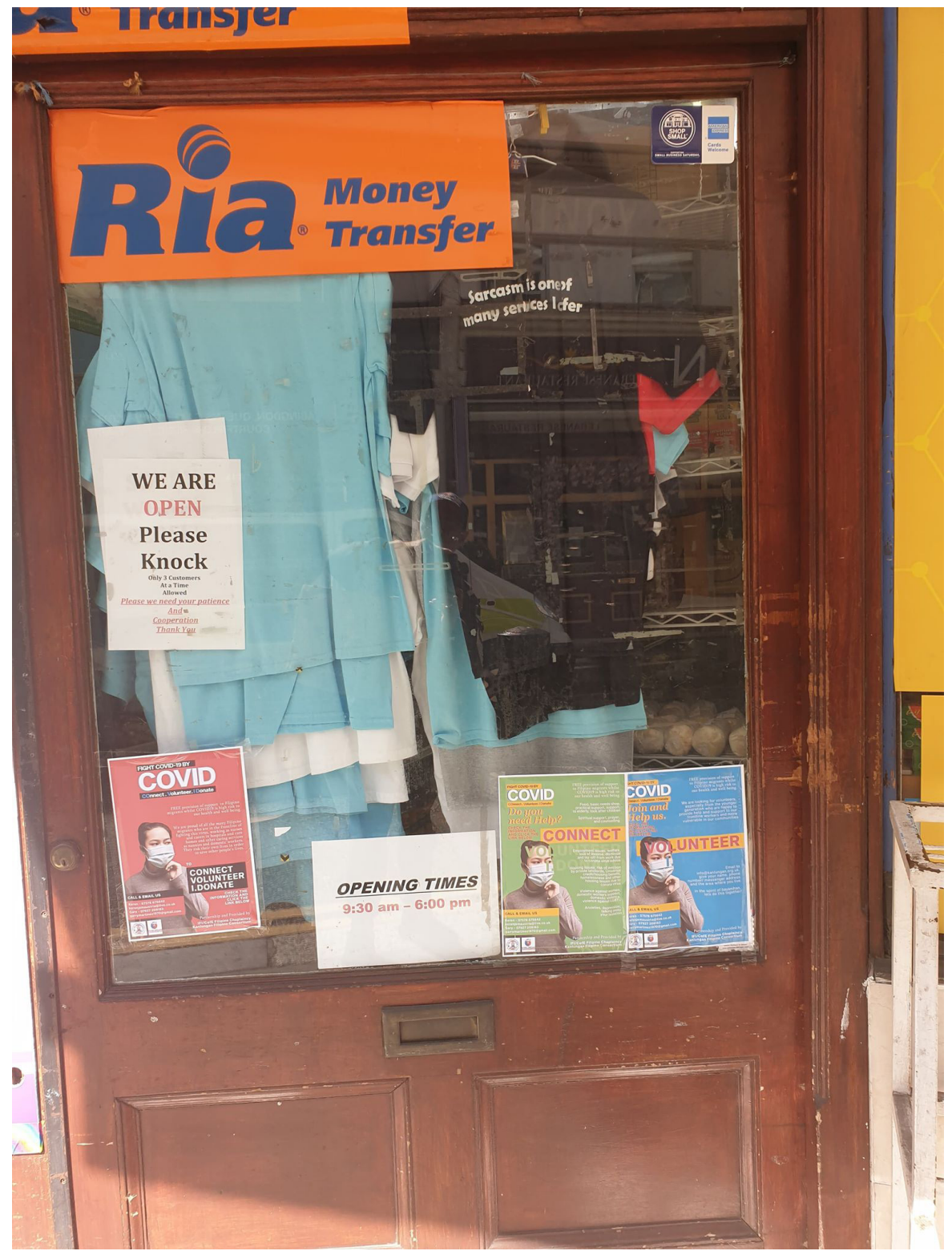

Source: Courtesy of Kanlungan. 
claps $^{3}$ from the British public and the prime minister did not translate into adequate pay rises, sufficient personal protective equipment, or secure immigration status for staff (Campbell 202 I; UK Government and Parliament Petitions 2020; UK Government and Parliament Petitions 202I), nor did it translate into better protection from the Philippine government, as its offer to exchange workers for vaccines revealed (Morales 202I). Community groups and charities, such as Kanlungan, responded to the health and economic impact of the crisis on communities who were either not able to access or not eligible for COVID-I9 government support owing to their immigration status ${ }^{4}$ by filling in these gaps in welfare provision with emergency grocery delivery, mental health support, and the dissemination of COVID-I9 guidelines in community languages (Galam 2020, pp.452-453; Kanlungan Filipino Consortium 202I).

The situation faced by Filipino health and social care workers exposed the failure and emptiness of these two narratives. Celebrating Filipino healthcare workers for their sacrifices and contributions, such as - ironically - administering the first COVID-I9 vaccine in the UK (Chikoko 2020), may have made them heroes, but this public discourse did not translate into material and economic security. For Filipinos 'at home', the crisis demonstrated the need to fundamentally question the hero narrative surrounding OFWs. The hardship faced by OFWs must be recognised and appreciated, but a new narrative must be forged, one of empowered immigration through informed decision-making for migrants about their work and immigration, systematic access to adequate support services and knowledge about labour rights, and sustained agency. As Cielito Caneja (2020, p.2), a Filipino nurse in London, stated: 'Please do not call me a hero. ... I am a nurse delivering my oath and this is what we do, day in and day out. Long before the pandemic.'

\section{Calls for change amid uncertain post-COVID futures}

The tragedy of the Filipino is transnational. Whether they were abroad - dying from caring for the sick - or in the Philippines - experiencing loss of income, being killed in the streets for breaking lockdown rules, or being 'red-tagged' as communists (Talabong 2020; UN News 202I) - for many Filipinos, the present has become dire and the future deeply uncertain.

The pandemic required studies of the Filipino global nation and other diasporas to be re-evaluated. Much like the climate emergency, the long-term disruptive impact of the pandemic will lead to a reassessment 
of global migration, healthcare and welfare regimes, and the further fragmentation of imagined global communities. The crises generated by the pandemic proved again the precarious position of both nation states and migrant workers caused by global capitalism. Nation states faced a near collapse of healthcare provision without the constant supply of migrant workers, while migrant workers were caught in between nation states, with neither able to properly care for them (Galam 2020, p.442; Ghosh 2020, p.92). On a micro scale, politicians, academics, and civil society at large must ask themselves, as Cielito, the Filipino nurse in London, asked, 'who cares for the carers?' (Caneja 2020, p.3).

Finally, the pandemic brought attention to issues that migrants' rights activists and community members had been campaigning on for years (Galam 2020, p.442). It has been bittersweet to consider that public and academic interest in these issues expanded only after such tragedy had occurred. Much of the COVID-I9 era's activism was trauma-responsive: the international Black Lives Matter and Stop Asian Hate movements, conversations in the UK about violence against women in the wake of Sarah Everard's murder, and reckonings with systemic racism and inequalities in public health as non-White people continued to bear the brunt of the pandemic. There is an urgent need to listen to community members and resource their leadership in academic research and political decision-making, as opposed to making them the subject to/of research and relying on trauma to mobilise and beg for political capital. COVID-I9 revealed injustices in the immigration, healthcare, education, and many other public systems. Let us not wait until the next global crisis to take these experiences seriously.

\section{Notes}

I. A literal 'post-COVID' world may never occur. Much like the 'post' in postcolonialism is used to emphasise the impact of colonialism and empire on the contemporary moment, my use of 'post' in this chapter is an acknowledgement that any future occurring after the outbreak in late 20I9-early 2020 will be shaped by the pandemic and the global response to it.

2. A more general repertory of news coverage relating to healthcare workers as heroes during the pandemic can be found in Mohammed et al. (202I).

3. During the first lockdown, people across the UK, including Prime Minister Boris Johnson and other senior politicians, took part in weekly claps on their doorsteps to show appreciation and support for health and social care workers. 
4. In the UK, under what is known as the 'hostile environment' policy, migrants have no recourse to public funds, unless they have been granted indefinite leave to remain.

\section{Acknowledgements}

I am indebted to my Kanlungan colleagues and the Filipino community who inform, guide, and support me in my work to highlight the experiences of our kababayan. Thank you.

\section{References}

Abel, Guy J.; and Gietel-Basten, Stuart. (2020). 'International remittance flows and the economic and social consequences of COVID-I9'. Environment and Planning A: Economy and Space, vol. 52, no. 8, pp. I480-I482. https:// doi.org/IO.I I 77/03085 I 8X2093 I I I I

Almendral, Aurora. (2018). 'Why Io million Filipinos endure hardship abroad as overseas workers'. National Geographic, December. https://perma.cc /8P 3 M-JQXE [Last accessed I4 April 202I].

Anderson, Benedict. (1983). Imagined Communities: Reflections on the Origin and Spread of Nationalism. UK: Verso.

Baker, Carl. (2020). NHS Staff from Overseas: Statistics. UK: House of Commons Library. https://perma.cc/4H8Y-KWQU [Last accessed I3 April 202I].

Calonzo, Andreo. (2020). 'Philippines relaxes ban on nurses leaving for jobs overseas'. Bloomberg, I 4 April. https://perma.cc/HNF $4-7 \mathrm{~S}_{3} \mathrm{C}$ [Last accessed I5 April 202I].

Campbell, Denis. (202I). 'NHS staff should get $5 \%$ payrise next year, says thinktank'. The Guardian, 2I March. https://perma.cc/7EMZ-W8B5 [Last accessed I4 April 202I].

Caneja, Cielito. (2020). 'The Coronavirus Collective: Who cares for the carers?' Sushruta Journal of Health Policy and Opinion, vol. I3, no. 3, pp. I-3. https://doi.org/IO.38 I92/I3.3.I I

Commission on Filipinos Overseas. (2013). Stock Estimates of Overseas Filipinos as of Dec. 2013. https://perma.cc/LE7 7 -8VE5 [Last accessed I 5 April 202I].

Chikoko, Cryton. (2020). 'How Britain could truly honour its Filipino frontline workers'. Each Other, I8 December. https://perma.cc/Y28C-ZUXQ [Last accessed I5 April 202I]. 
Choy, Catherine C. (2003). Empire of Care: Nursing and Migration in Filipino American History. USA: Duke University Press.

David, Emmanuel. (2018). 'Transgender archipelagos'. Transgender Studies Quarterly, vol. 5, no. 3, pp. 332-354. http://dx.doi.org/IO.I2 I 5/23289252 $-6900724$

Day, Aasma. (202I). 'Why so many Filipino health workers are dying of Covid-I9'. Huffington Post, I4 April. https://perma.cc/H8EX-Y2AM [Last accessed I 8 April 202I]

Fernandez, Alejandro. (2020). I still can't believe it So sad to get a phone call early this morning from our common friend. I [...]. Facebook, 8 April. https://perma.cc/FWN4-7NJ6 [Last accessed I 8 April 202I].

Galam, Roderick. (2020). 'Care and solidarity in the time of Covid-I9: The pandemic experiences of Filipinos in the UK'. Philippine Studies: Historical and Ethnographic Viewpoints, vol. 68, no. 3-4, pp. 44 I-464. https://doi.org /IO.I353/phs.2020.0028

Ghosh, Ambar K.; and Chaudhury, Anasua B.R. (2020). 'Migrant workers and the ethics of care during a pandemic', in Ranabir Samaddar (ed.) Borders of an Epidemic: Covid-I9 and Migrant Workers. India: Maharniban Calcutta Research Group, pp. 9I-97.

Guevarra, Anna R. (2009). Marketing Dreams, Manufacturing Heroes: The Transnational Labor Brokering of Filipino Workers. USA: Rutgers University Press.

Isidro, Charissa. (2020). 'They've filled essential health-care roles for decades. Now, the coronavirus is killing them'. The Daily Beast, I 4 November [online]. https://perma.cc/B4GL-VYQ3 [Last accessed I 8 April 202I].

Kanlungan Filipino Consortium. (202I). COVIDI9 Filipino Response. https:// perma.cc/SP7C-2REW [Last accessed I4 April 202I].

Kearney, Lesa; Lennane, Simon; Woodmand, Ella; Kursumovic, Emira; and Cook, Tim. (2020). 'At least 23 nationalities among NHS staff killed by covid'. HSJ, I9 May. https://perma.cc/PN8H-KH22 [Last accessed I 8 April 202I].

Maddrell,Avril.(2020).'Bereavement, grief, and consolation:Emotional-affective geographies of loss during COVID-I9'. Dialogues in Human Geography, vol. Io, no. 2, pp. IO7-I I I. https://doi.org/IO. I I 77/2043820620934947

Magsambol, Bonz. (2020). 'DOH asks for volunteer health workers vs coronavirus, to be paid $\mathrm{P}_{5} 00$ a day'. Rappler, 27 March. https://perma.cc/A8N4 -C6SZ [Last accessed io June 2020]. 
Mohammed, Shan; Peter, Elizabeth; Killackey, Tieghan; and Maciver, Jane. (202I). "The "nurse as hero" discourse in the COVID-I9 pandemic: A poststructural discourse analysis'. International Journal of Nursing Studies, vol. I I7, pp. I-I I. https://doi.org/IO.IOI6/j.ijnurstu.202I.I03887.

Morales, Neil J. (202I). 'Philippines offers nurses in exchange for vaccines from Britain, Germany'. Reuters, 2 I February. https://perma.cc/N9BD -P6VX [Last accessed I4 April 202I].

Parreñas, Rhacel S. (200I). Servants of Globalization: Women, Migration and Domestic Work. USA: Stanford University Press.

Rocamora, Joyce Ann L. (20I8). 'OFWs: Modern-day heroes still'. Philippine News Agency, 27 August. https://perma.cc/T 5LZ-MTUL [Last accessed I I April 202I].

Talabong, Rambo. (2020). 'QC officials maul, drag fish vendor for not wearing face mask'. Rappler, 28 April. https://perma.cc/EU2T-V7FF [Last accessed I4 April 202 I].

UK Government and Parliament Petitions. (2020). Give Non-British Citizens Who Are NHS Workers Automatic Citizenship. https://perma.cc/9RVL-5 $\mathrm{PR}_{3}$ [Last accessed 20 August 2020].

UK Government and Parliament Petitions. (202I). Offer Indefinite Leave to Remain to All NHS and Social Care Workers. https://perma.cc/6PX $3-\mathrm{A}_{95} \mathrm{Z}$ [Last accessed I4 April 202I].

UN News. (202I). Philippines: UN Rights Office Appalled over Simultaneous Killings of 'Red-Tagged' Activists. 3 March. https://perma.cc/N828-9H98 [Last accessed I 8 April 202I].

World Bank. (2019).Personal Remittances, Received (\% of GDP) - Philippines, 20I9. https://perma.cc/SP4R-J466 [Last accessed 20 August 2020]. 